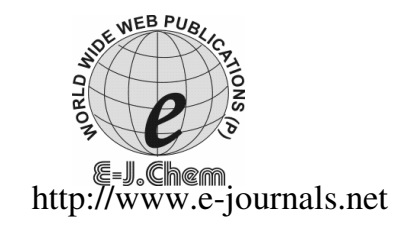

ISSN: 0973-4945; CODEN ECJHAO

E-Journal of Chemistry

2011, 8(3), 966-976

\title{
Combination of First Derivative Spectrophotometry and H-Point Standard Addition Method for Simultaneous Determination of Guaifenesin and Theophylline in Cough Syrup
}

\author{
R. HAJIAN*, N. SHAMS and Z. DAVARPANAH \\ Young Researchers Club, College of Science, Chemistry Department, \\ Islamic Azad University Branch of Gachsaran, \\ Gachsaran, 75818-63876, Iran \\ hajian@iaug.ac.ir
}

Received 20 February 2010; Accepted 15 April 2010

\begin{abstract}
Combination of first derivative spectrophotometric and H-point standard addition method (HPSAM) has been applied for simultaneous determination of guaifenesin and theophylline. First derivative signals at the two pairs of wavelengths, $282.0-290.2 \mathrm{~nm}$ and $277.4-287.8 \mathrm{~nm}$ were monitored with the addition of standard solutions of both guaifenesin and theophylline in the ratio of 1:1. The method is able to accurately determine guaifenesin and theophylline (1:5 to $10: 1)$ mole ratios. Accuracy and reproducibility of the determination method on the various amounts of guaifenesin and theophylline with known concentrations were evaluated in their binary mixtures. The recommended procedure was successfully applied to some cough syrups and synthetic mixtures with satisfactory results.
\end{abstract}

Keywords: Guaifenesin, Theophylline, Spectrophotometry, H-Point Standard Addition Method, First derivative spectra, Cough syrups

\section{Introduction}

To develop safe cough/cold products that deliver optimal efficacy, it is necessary to design formulations that provide the most favorable plasma concentration-time profiles of each active ingredient along with key metabolites. Two common actives in such products are guaifenesin (GU) and Theophylline (TP).

Guaifenesin is an expectorant believed to stimulate receptors that initiate a reflex secretion of respiratory tract fluid, thereby increasing the volume while decreasing the viscosity of mucus in the lungs. This action facilitates removal of mucus and reduces irritation of the bronchial tissue ${ }^{1-3}$. 
Theophylline, one of the main metabolites of $\mathrm{CF}^{4}$, has been widely used to treat asthma and brochospasm in adults ${ }^{5}$. Theophylline is a bronchodilator that is widely used in the treatment of asthma and bronchospasm in adults. It is one of the most commonly prescribed pharmaceuticals ${ }^{6}$ and was one of the three drugs most frequently monitored by pharmacokinetics services in the US Veterans Affairs medical centers ${ }^{7}$. A developmental study found that theophylline caused clastogenic but not genotoxic effects in human lymphocytes after long-term exposure ${ }^{8}$.

The use of the mixture of TP and GU in the symptomatic treatment of bronchial asthma and other bronchospastic conditions is well established in pharmaceutical formulations ${ }^{9}$. Theophylline G syrup contains $50 \mathrm{mg}$ TP and $30 \mathrm{mg} \mathrm{GU}$ in each $5 \mathrm{~mL}$. TP and GU are the subject of monographs in both the United States Pharmacopoeia (USP) ${ }^{10}$, and the British Pharmacopoeia (BP) in which these drugs were determined by HPLC methods ${ }^{11}$.

For determination of theophylline in biological fluids many methods such as UV-Vis spectrophotometry ${ }^{12}, \mathrm{HPLC}^{13-15}, \mathrm{HPTLC}^{16}, \mathrm{GC}^{17}, \mathrm{GC}^{-\mathrm{MS}^{18}}$, Fluorescence immunoassay, Fluorescence Polarized immunoassay, Ratio Immunoassay ${ }^{19-22}$, capillary electrophoresis ${ }^{23,24}$, and reflectance photometry assay ${ }^{25}$, are reported. Most of these methods are insensitive to concentrations obtained after single dose administration of this drug or otherwise time consuming and/or expensive.

Several other methods in research articles have also been reported for the analysis of GU either in pure or in pharmaceutical forms as well as in biological fluids and tissues, such as HPLC ${ }^{26-29}$ and capillary electrophoresis ${ }^{30}$.

Since UV-Visible spectrophotometry is a rapid, sensitive and inexpensive analytical tool, it is appropriate for dosage control of pharmaceutical preparations. Despite the mentioned advantages, spectroscopy techniques (such as other analytical techniques) suffer from multiplicative (matrix effect) and additive (direct interference) errors. The problem of multiplicative errors can be simply solved by using method of standard addition (MOSA).The applicability of MOSA is limited to the cases where no direct interference (additive error) is present. Additive errors are observed when two or more species in sample have spectral overlapping. In such cases determination of one analyte in the presence of interferent(s) by classical methods (e.g., standard addition or external standard calibration) is not possible.

Various multivariate methods for handling nonselective signals in spectrophotometric analysis have been proposed. Principal component and partial least squares solutions require no explicit data about the individual interferences to be known in order to model and to eliminate them ${ }^{31}$. However, they require a set of calibration samples with known concentrations of the analyte to be determined and the concentration of each interferent in different samples to be varied to allow the calibration algorithm to model its effect. In the most applications of multivariate chemometric methods the matrix effects are not considered.

Disadvantages of the zero-crossing derivative method are the risk of small drifts of the cross over points and the fact that the working wavelengths do not coincide with the peaks. This may be particularly dangerous when the slope of the spectra is very high, with consequent loss of precision and accuracy.

The generalized standard addition method (GSAM) developed by Saxberg and Kowalski is a multivariate extension of the conventional standard addition method for simultaneous multicomponent determinations ${ }^{32}$. The GSAM looks promising as a method by 
which both interferences and the matrix effects can be overcome simultaneously. In this way, Falco et al. proposed a modification of MOSA, the H-point standard addition method (HPSAM), which makes it possible to determine the concentration of analyte in the presence of a direct interferent and even the concentration of interferent can be determined ${ }^{33}$. The basis of the method for spectrophotometric determination of binary mixtures with extensively overlapped spectra and in the presence of proportional errors was established $^{33,34}$. This method has been frequently applied to improve results in different analytical techniques, including spectrophotometry ${ }^{35-38}$, spectrofluorometry ${ }^{39}$, kinetic specterophotometry ${ }^{40-42}$, chromatographic techniques ${ }^{43}$ and stripping voltammetry ${ }^{44-46}$. Recently the method is used for spectral curve deconvolution in micelar system and spectrophotometric study of complexation equilibria ${ }^{47,48}$.

In 1995 Falco et al. proposed a modification of HPSAM, H-point standard addition with simultaneous addition of both analytes that permits the resolution of both species from a unique calibration set by making the simultaneous addition of both analytes ${ }^{49}$. The method is based on selection two pairs of independent variables in such a way that in each pair the analytical signal due to the one of the species is constant and for another one as possible as be different. Two pairs of standard addition plots can be obtained by plotting the analytical signals in two pairs of selected independent variables versus the analytes concentrations that are added to the sample solution simultaneously and in a constant ratio. Each pair of plots has an intersection point that its coordinate on the concentration axis is $-\mathrm{C}_{\mathrm{A}}$. The requirement of selecting only two pairs of wavelength makes this method simpler to use in respect to GSAM.

In this study the combination of derivative spectrophotometric (DS) and $H$-point standard addition methods with simultaneous addition of both analytes were proposed for simultaneous determination of both drugs in liquid or solid dosage forms. To the best of our knowledge it is the first report of the combination DS-HPSAM with simultaneous addition of both analytes.

\section{Theoretical background}

Consider a binary mixture of guaifenesin and theophylline compounds with typical spectra shown in Figure 1. In the absence of matrix effect the measured absorbance of the sample at each wavelength will be addition of the individual absorbances of the guaifenesin and theophylline species at this wavelength:

$$
A_{i}=\varepsilon_{i, g} c_{g}^{0}+\varepsilon_{i, t} c_{t}^{0}+A_{i}^{0}
$$

Where $A_{i}$ is the absorbance of the mixture at wavelength $\lambda_{i}, c_{g}^{0}$ and $c_{t}^{0}$ are the concentrations of guaifenesin and theophylline in the sample, $\varepsilon_{\mathrm{i}, \mathrm{g}}$ and $\varepsilon_{\mathrm{i}, \mathrm{t}}$ are the molar absortivity coefficients at wavelength $\lambda_{i}$ for corresponding compounds and $A_{i}^{0}$ is the residual absorbance at $\lambda_{\mathrm{i}}$, which can be nearly omitted by subtracting the absorbance of blank. So, the Equation 1 can be written as:

$$
\mathrm{A}_{\mathrm{i}}=\mathrm{A}_{\mathrm{i}, \mathrm{g}}^{0}+\mathrm{A}_{\mathrm{i}, \mathrm{t}}^{0}
$$

$\mathrm{A}_{\mathrm{i}, \mathrm{g}}^{0}$ and $\mathrm{A}_{\mathrm{i}, \mathrm{t}}^{0}$ are the individual absorbances of the guaifenesin and theophylline compounds in the considered sample. According to HPSAM, the quantification of each analyte $\mathrm{X}$ (guaifenesin or theophylline) in the presence of the other as an interferent $\mathrm{Y}$, can be performed by the construction of two standard addition plots for the analyte, with $\mathrm{M}_{\mathrm{X}, 1}$ and with $\left(\mathrm{C}_{\mathrm{H}(\mathrm{X})}, \mathrm{A}_{\mathrm{H}(\mathrm{Y})}\right)$ coordinates. For example if guaifenesin is considered as analyte, the $\mathrm{H}$ point depends on its concentration $\mathrm{c}_{\mathrm{g}}^{0}$ as: 


$$
\begin{aligned}
-\mathrm{c}_{\mathrm{H}(\mathrm{s})} & =\frac{\left(\mathrm{A}_{\mathrm{g}, 1}^{0}-\mathrm{A}_{\mathrm{g}, 2}^{0}\right)+\left(\mathrm{A}_{\mathrm{t}, 1}^{0}-\mathrm{A}_{\mathrm{t}, 2}^{0}\right)}{\left(\mathrm{M}_{\mathrm{g}, 1}-\mathrm{M}_{\mathrm{g} 2}\right)} \\
& =-\mathrm{c}_{\mathrm{s}}^{0}+\frac{\left(\mathrm{A}_{\mathrm{t}, 1}^{0}-\mathrm{A}_{\mathrm{t}, 2}^{0}\right)}{\left(\mathrm{M}_{\mathrm{g}, 1}-\mathrm{M}_{\mathrm{g}, 2}\right)}
\end{aligned}
$$

By selecting the $\lambda_{1}$ and $\lambda_{2}$ in such away that the theophylline absorbance values are equal

$$
\mathrm{A}_{\mathrm{t}, 1}=\mathrm{A}_{\mathrm{t}, 2}
$$

Then the abscissa of the H-point will be the sulfacetamide concentration in the sample, $\mathrm{c}_{\mathrm{g}}^{0}$. The concentration of theophylline can be determined according to conventional HPSAM from the $A_{H}$ value and a calibration plot obtained separately for theophylline.

HPSAM based on simultaneous standard addition of the two species as reported by Campins-Falco $e t a l^{49}$ permits one to obtain concentration of both analyte in the sample from a unique calibration set. The required data to apply the method are the response of the sample and the response of the sample spiked with known amounts of both analytes at previously selected variables.

For simultaneous determination of guaifenesin and theophylline by spectrophotometry, let us suppose that $\lambda_{1}$ and $\lambda_{2}$ are selected wavelengths according to Equation 5. Because the additions are made from a standard mixture of both analytes, the relation of the added concentrations between species guaifenesin and theophylline is the same in all the solutions prepared to apply the method. By representing the analytical signal, absorbance at two previously selected wavelengths $\lambda_{1}$ and $\lambda_{2}$ versus the concentration added of sulfacetamide, two lines would be obtained with intercepts $\left(\mathrm{A}_{\mathrm{g}, 1}^{0}+\mathrm{A}_{\mathrm{t}, 1}^{0}\right)$ and $\left(\mathrm{A}_{\mathrm{g}, 2}^{0}+\mathrm{A}_{\mathrm{t}, 2}^{0}\right)$ and slopes:

$$
\begin{array}{lll}
\text { Slope at } \lambda_{1} \text { potential: } & \mathrm{M}_{\mathrm{g}, 1}+\left(\mathrm{c}_{\mathrm{t}}^{\mathrm{i}} / \mathrm{c}_{\mathrm{g}}^{\mathrm{i}}\right) \mathrm{M}_{\mathrm{t}, 1} & \mathrm{i}=0,1, \ldots, \mathrm{n} \\
\text { Slope at } \lambda_{2} \text { potential: } & \mathrm{M}_{\mathrm{g}, 2}+\left(\mathrm{c}_{\mathrm{t}}^{\mathrm{i}} / \mathrm{c}_{\mathrm{g}}^{\mathrm{i}}\right) \mathrm{M}_{\mathrm{t}, 2} & \mathrm{i}=0,1, \ldots, \mathrm{n}
\end{array}
$$

$\mathrm{M}_{\mathrm{g}, 1}, \mathrm{M}_{\mathrm{t}, 1}, \mathrm{M}_{\mathrm{g}, 2}$ and $\mathrm{M}_{\mathrm{t}, 2}$ are the slopes due to the addition of guaifenesin and theophylline in the lines obtained at $\lambda_{1}$ and $\lambda_{2} ; \mathrm{c}_{\mathrm{g}}^{\mathrm{i}}$ and $\mathrm{c}_{\mathrm{t}}^{\mathrm{i}}$ are the concentration of considered pharmaceutical compounds added in the i solution; $n$ is the number of additions. When $i=0$ corresponds with the solution where only the sample exists. Both calibration lines intersect at the $H$-point, with coordinates $\left(\mathrm{c}_{\mathrm{H}(\mathrm{g})}, \mathrm{A}_{\mathrm{H}(\mathrm{t})}\right)$, where _ $\mathrm{c}_{\mathrm{H}(\mathrm{g})}$ is the unbiased concentration of guaifenesine concentration. In this case the abscissa of the $\mathrm{H}$-point will be:

$$
-\mathrm{c}_{\mathrm{H}(\mathrm{g})}=\frac{\left(\mathrm{A}_{\mathrm{g}, 1}^{0}-\mathrm{A}_{\mathrm{g}, 2}^{0}\right)+\left(\mathrm{A}_{\mathrm{t}, 1}^{0}-\mathrm{A}_{\mathrm{t}, 2}^{0}\right)}{\left(\mathrm{M}_{\mathrm{g}, 2}-\mathrm{M}_{\mathrm{g}, 1}\right)+\left(\mathrm{c}_{\mathrm{t}}^{\mathrm{i}} / \mathrm{c}_{\mathrm{g}}^{\mathrm{i}}\right)\left(\mathrm{M}_{\mathrm{t}, 2}-\mathrm{M}_{\mathrm{t}, 1}\right)}=\frac{\left(\mathrm{A}_{\mathrm{g}, 1}^{0}-\mathrm{A}_{\mathrm{g}, 2}^{0}\right)}{\left(\mathrm{M}_{\mathrm{g}, 2}-\mathrm{M}_{\mathrm{g}, 1}\right)}
$$

The incorrigible error due to presence of theophylline, in spite of its concentration is not constant, has been transformed into a constant systematic error as the HPSAM basis predicts. It can be proved that $\mathrm{A}_{\mathrm{H}(\mathrm{p})}$ is equivalent to:

$$
\mathrm{A}_{\mathrm{H}(\mathrm{t})}=\mathrm{A}_{\mathrm{t}, 1}^{0}-\left(\mathrm{c}_{\mathrm{t}}^{\mathrm{i}} / \mathrm{c}_{\mathrm{g}}^{\mathrm{i}}\right) \mathrm{M}_{\mathrm{t}, 1} \mathrm{c}_{\mathrm{H}(\mathrm{g})}=\mathrm{A}_{\mathrm{t}, 2}^{0}-\left(\mathrm{c}_{\mathrm{t}}^{\mathrm{i}} / \mathrm{c}_{\mathrm{g}}^{\mathrm{i}}\right) \mathrm{M}_{\mathrm{t}, 2} \mathrm{c}_{\mathrm{H}(\mathrm{g})}
$$

In the same way as for theophylline, by selecting two wavelengths $\lambda_{3}$ and $\lambda_{4}$ in such a way that sulfacetamide present the same absorbance $A_{g, 3}=A_{g, 4}$ similar expressions can be obtained for theophylline. The analogous expressions for Eqs. 8 and 9 in the analysis of prednisolone are: 


$$
\begin{gathered}
-\mathrm{c}_{\mathrm{H}(\mathrm{p})}=\frac{\left(\mathrm{A}_{\mathrm{t}, 3}^{0}-\mathrm{A}_{\mathrm{t}, 4}^{0}\right)+\left(\mathrm{A}_{\mathrm{g}, 3}^{0}-\mathrm{A}_{\mathrm{g}, 4}^{0}\right)}{\left(\mathrm{M}_{\mathrm{t}, 4}-\mathrm{M}_{\mathrm{t}, 3}\right)+\left(\mathrm{c}_{\mathrm{t}}^{\mathrm{i}} / \mathrm{c}_{\mathrm{g}}^{\mathrm{i}}\right)\left(\mathrm{M}_{\mathrm{g}, 4}-\mathrm{M}_{\mathrm{t}, 3}\right)}=\frac{\left(\mathrm{A}_{\mathrm{p}, 3}^{0}-\mathrm{A}_{\mathrm{p}, 4}^{0}\right)}{\left(\mathrm{M}_{\mathrm{p}, 4}-\mathrm{M}_{\mathrm{p}, 3}\right)} \\
\mathrm{A}_{\mathrm{H}(\mathrm{g})}=\mathrm{A}_{\mathrm{g}, 3}^{0}-\left(\mathrm{c}_{\mathrm{t}}^{\mathrm{i}} / \mathrm{c}_{\mathrm{g}}^{\mathrm{i}}\right) \mathrm{M}_{\mathrm{g}, 3} \mathrm{c}_{\mathrm{H}(\mathrm{t})}=\mathrm{A}_{\mathrm{g}, 4}^{0}-\left(\mathrm{c}_{\mathrm{t}}^{\mathrm{i}} / \mathrm{c}_{\mathrm{g}}^{\mathrm{i}}\right) \mathrm{M}_{\mathrm{g}, 4} \mathrm{c}_{\mathrm{H}(\mathrm{t})}
\end{gathered}
$$

The precision of the obtained results will depend on the value of the denominator in Eqs. 8 and 10. The higher the value of the denominator, the higher the precision of the obtained results. So, a previous optimization of the pairs of wavelengths can be done. In addition, the precision of the results will also depend on the relation of $\left(\mathrm{c}_{\mathrm{t}}^{\mathrm{i}} / \mathrm{c}_{\mathrm{g}}^{\mathrm{i}}\right)$ and the sample composition. Both variables will be studied in the results and discussion section.

In this report because of the highly overlapped spectra between guaifenesin and theophylline, selection of the two pair of wavelengths according to the HPSAM theory was not possible. Therefore we used first derivative spectra as the original datum.

\section{Experimental}

All the chemicals were of analytical grade and were purchased from Merck (Darmstadt, Germany) unless stated otherwise. Doubly distilled water was used throughout. Guaifenesin and theophylline were purchased from Ramopharmin and Doctor Abidi pharmaceutical companies (Tehran, Iran), respectively.

A $1.0 \times 10^{-3} \mathrm{~mol} \mathrm{~L}^{-1}$ guaifenesin solution was prepared daily by dissolving 0.0198 g guaifenesin (99\%) by doubly distilled water in a $100-\mathrm{mL}$ volumetric flask. The solution was kept in a refrigerator at $4{ }^{\circ} \mathrm{C}$ and in dark. More dilute solutions were prepared by serial dilution with water.

A $1.0 \times 10^{-3} \mathrm{~mol} \mathrm{~L}^{-1}$ theophylline solution was prepared daily by dissolving $0.0180 \mathrm{~g}$ theophylline hydrochloride (99\%) by doubly distilled water in a $100 \mathrm{~mL}$ volumetric flask. The solution was kept in a refrigerator at $4{ }^{\circ} \mathrm{C}$ and in dark. More dilute solutions were prepared by serial dilution with water. Britton-Robinson (B-R) buffers $\left(0.1 \mathrm{~mol} \mathrm{~L}^{-1}\right.$ in phosphate, acetate and borate) in the $\mathrm{pH}$ range of 2-9 were used, throughout.

\section{Apparatus}

UV-Vis absorption spectra are measured on a UV-Vis spectrophotometer, Perkin Elmer (Lambda 25), with the use of $1.0 \mathrm{~cm}$ quartz cells. A Pentium IV (2.53 MHz) computer controlled all of the setting and data processing. A pH-meter (Metrohm, Model 691) with a double junction glass electrode was used to check the $\mathrm{pH}$ of the solutions.

\section{Preparation of real samples}

Serum/or whole blood samples were obtained and stored frozen until the assay. Into each of 10 centrifugation tubes containing a certain concentration of guaifenesin and/or theophylline, $0.10 \mathrm{~mL}$ of the human serum/or whole blood sample was transferred, and then mixed well with $1.0 \mathrm{~mL}$ of methanol to precipitate the blood proteins. The precipitated proteins were separated by centrifuging of the mixture for $20 \mathrm{~min}$ at $4000 \mathrm{rpm}$. The clear supernatantlayer was filtered through a $0.45 \mu \mathrm{m}$ milli-pore filter to produce protein-free serum/or whole blood. The protein-free sample was transferred into a $25 \mathrm{~mL}$ calibrated flask, completed to the volume with B-R buffer of $\mathrm{pH} 9.0$ and then introduced to the optical cell.

To assay cough syrup, ca.1.0 mL of syrup was transferred into a $100 \mathrm{~mL}$ measuring flask and diluted to the mark by doubly distilled water. Further dilution with water was achieved to get a reasonable concentration range. 


\section{Recommended procedure}

An aliquot of the solution containing guaifenesin and/or theophylline and $1 \mathrm{~mL}$ BrittonRobinson buffer solution ( $\mathrm{pH} 9.0$ ) were added into a $10 \mathrm{~mL}$ volumetric flask and made up to the mark with doubly distilled water. The solution was then allowed to stand for $10 \mathrm{~min}$ at room temperature. Then, the first derivative spectra of the working solutions were recorded against reagent blank solution in the range of $200-400 \mathrm{~nm}$ with $\Delta \lambda=0.5 \mathrm{~nm}$ and a scan speed of $250 \mathrm{~nm} / \mathrm{min}$. Quantitative results were obtained by addition of appropriate aliquots of standard solution of two pharmaceutical compounds and plotting the first derivative values at 282.0 and $292.4 \mathrm{~nm}$ versus added concentrations of guaifenesin and at 277.4 and 287.8 $\mathrm{nm}$ versus the added concentrations of theophylline.

\section{Results and Discussion}

The absorption spectra of guaifenesin and theophylline under certain experimental conditions are shown in Figure 1. As can be seen in Figure 1, the maximum wavelengths of two compounds are very close to each other and their spectra are highly overlapped. Therefore, simultaneous determination of two pharmaceutical compounds in the presence of each other is impossible by HPSAM because of the limitation on wavelengths selection. Consequently, we used the combination of first derivative and HPSAM with simultaneous additions of both analytes for resolving of additive interference and matrix effect simultaneously.

\section{Effect of operational parameters}

In order to optimize the procedure for the simultaneous determination of guaifenesin and theophylline, we studied the effect of $\mathrm{pH}$ on the sensitivity and selectivity of two species separately. As it has been shown in Figure 2, there weren't significant changes in the absorption spectra of sulfacetamide and prednisolone in the $\mathrm{pH}$ range of 2-10, Therefore $\mathrm{pH}$ of 9.0 was selected for obtaining higher selectivity and omitting some ion interferences.

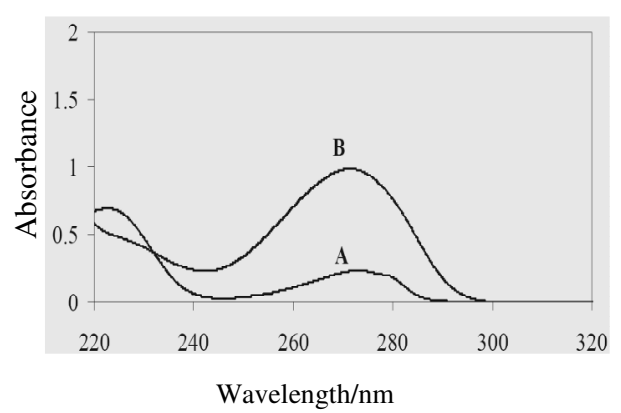

Figure 1. Zero order absorption spectra of (A) $10 \mu \mathrm{mol} \mathrm{L} \mathrm{L}^{-1}$ guaifenesin and (B) 10 $\mu \mathrm{mol} \mathrm{L}{ }^{-1}$ theophylline at $\mathrm{pH} 10.0$.

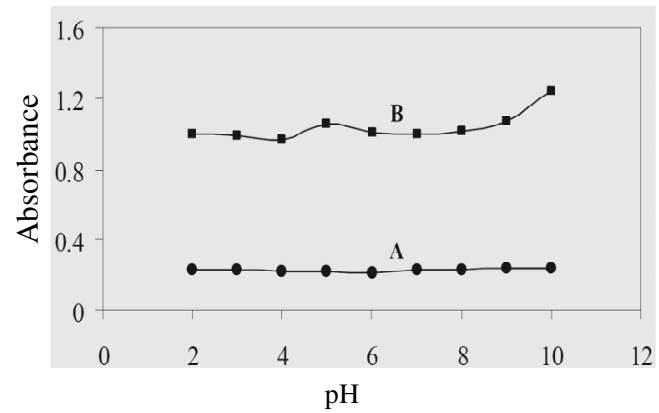

Figure 2. Effect of $\mathrm{pH}$ on the maximum absorption spectra of guaifenesin and theophylline. Conditions: Britton Robinson buffer $\left(0.01 \mathrm{~mol} \mathrm{~L}^{-1}\right), \quad$ guaifenesin concentration $10 \mu \mathrm{mol} \mathrm{L}^{-1}$, theophylline concentration $10 \mu \mathrm{mol} \mathrm{L}{ }^{-1}$

\section{Wavelength selection}

To select the appropriate wavelength pairs for using HPSAM the following principles applied. At these selected wavelengths the derivative signals must be linear with concentrations and the interferent derivative signal must be equal remains unchanged by changing the analyte concentration. The analytical signal obtained from a mixture containing the analyte and the 
interfering should be equal to the sum of the individual signals of the two components. In addition, the difference in the slopes of the two straight lines measured at two selected wavelengths must be as large as possible in order to get good accuracy and sensitivity ${ }^{50,51}$.

Consequently, for determination of guaifenesin and theophylline, we selected two pairs of wavelengths on the first derivative spectra of compounds. In this case there were many pairs of wavelengths. As it is observed from Figure 3, the best wavelength pairs were 282.0-288.2 and 277.4-287.8 $\mathrm{nm}$ for determination of guaifenesin and theophylline respectively. Standard solutions of two species were initially tested to validate the applicability of the chosen wavelengths. Figure 4 is a typical H-point standard addition calibration lines constructed at selected wavelengths.

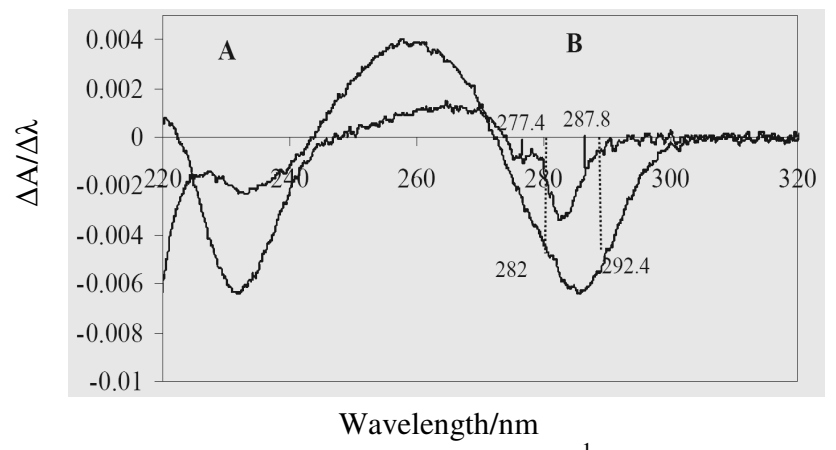

Figure 3. First derivative spectra of (A) $10 \mu \mathrm{mol} \mathrm{L} \mathrm{L}^{-1}$ guaifenesin and (B) $10 \mu \mathrm{mol} \mathrm{L} \mathrm{L}^{-1}$ theophylline against blank at $\mathrm{pH}=10.0$. The dashed lines are selected wavelengths.
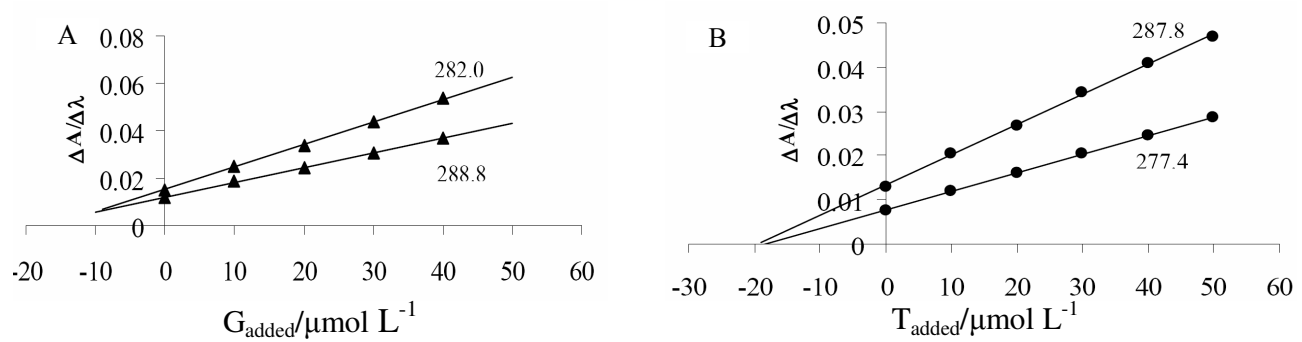

Figure 4. H-point standard additions-First Derivative plots for simultaneous determination of (A) guaifenesin $\left(10 \mu \mathrm{mol} \mathrm{L} \mathrm{L}^{-1}\right)$ and (B) theophylline $\left(20 \mu \mathrm{mol} \mathrm{L}^{-1}\right)$ concentrations at wavelengths $282.0,290.2 \mathrm{~nm}$ and $277.4,287.8 \mathrm{~nm}$ respectively at $\mathrm{pH}$ 9.0.

The effect of the concentration ratio of guaifenesin to theophylline on the accuracy of the method was also studied. From the gathered results it was concluded that the best results would be obtained when the concentration ratio of guaifenesin to theophylline in added standard is 1:1 ( $\mathrm{mol} / \mathrm{mol})$. Therefore, the concentration ratio of 1:1 was selected for further studies.

The utility of the developed method was tested by determining guaifenesin and theophylline in several synthetic mixed samples with different concentration ratios of two compounds. As can be seen from Table 1, the accuracy of the results is satisfactory in the concentration ratios of 1:12 to 10:1 for theophylline to guaifenesin.

\section{Reproducibility of the method}

To check the reproducibility of the method, six replicate experiments for the analysis of guaifenesin and theophylline mixtures were designed (Table 2). As it is shown standard deviations for two pharmaceutical compounds are satisfactory. 
Table 1. Determination of Guaifenesin and theophylline in some synthetic mixtures.

\begin{tabular}{|c|c|c|c|c|c|}
\hline \multirow{2}{*}{$A-C$ equation } & \multirow{2}{*}{$R$} & \multicolumn{2}{|c|}{$C_{\text {added }} / \mu \mathrm{mol} \mathrm{L}^{-1}$} & \multicolumn{2}{|c|}{$C_{\text {found }} / \mu \mathrm{mol} \mathrm{L}^{-1}$} \\
\hline & & GU & TP & GU & TP \\
\hline$\Delta A_{282.0}=0.00092 C+0.00914$ & 0.9999 & 10 & 10 & 10.20 & 9.54 \\
\hline$\Delta A_{292.4}=0.00033 C+0.00314$ & 0.9999 & & & & \\
\hline$\Delta A_{277.4}=0.00041 C+0.00411$ & 0.9998 & & & & \\
\hline$\Delta A_{287.8}=0.00067 C+0.00659$ & 0.9999 & & & & \\
\hline$\Delta A_{282.0}=0.00100 C+0.01881$ & 0.9993 & 20 & 20 & 19.60 & 20.20 \\
\hline$\Delta A_{292.4}=0.00035 C+0.00703$ & 0.9983 & & & & \\
\hline$\Delta A_{277.4}=0.00044 C+0.00861$ & 0.9991 & & & & \\
\hline$\Delta A_{287.8}=0.00071 C+0.01407$ & 0.9988 & & & & \\
\hline$\Delta A_{282.0}=0.00096 C+0.01507$ & 0.9999 & 10 & 20 & 11.90 & 19.10 \\
\hline$\Delta A_{292.4}=0.00032 C+0.00743$ & 0.9992 & & & & \\
\hline$\Delta A_{277.4}=0.00042 C+0.00766$ & 0.9999 & & & & \\
\hline$\Delta A_{287.8}=0.00070 C+0.01301$ & 0.9997 & & & & \\
\hline$\Delta A_{282.0}=0.00092 C+0.01266$ & 0.9995 & 20 & 10 & 16.19 & 9.90 \\
\hline$\Delta A_{292.4}=0.00036 C+0.00359$ & 0.9998 & & & & \\
\hline$\Delta A_{277.4}=0.00041 C+0.00506$ & 0.9997 & & & & \\
\hline$\Delta A_{287.8}=0.00068 C+0.00774$ & 0.9999 & & & & \\
\hline$\Delta A_{282.0}=0.00083 C+0.02648$ & 0.9938 & 50 & 10 & 46.75 & 10.35 \\
\hline$\Delta A_{292.4}=0.00035 C+0.00404$ & 0.9994 & & & & \\
\hline$\Delta A_{277.4}=0.00042 C+0.00726$ & 0.9970 & & & & \\
\hline$\Delta A_{287.8}=0.00068 C+0.00995$ & 0.9983 & & & & \\
\hline$\Delta A_{282.0}=0.00087 C+0.03152$ & 0.9977 & 10 & 50 & 9.73 & 50.83 \\
\hline$\Delta A_{292.4}=0.00057 C+0.02860$ & 0.9998 & & & & \\
\hline$\Delta A_{277.4}=0.00025 C+0.01113$ & 0.9993 & & & & \\
\hline$\Delta A_{287.8}=0.00078 C+0.03807$ & 0.9997 & & & & \\
\hline
\end{tabular}

Table 2. Replicate measurements of guaifenesin and theophylline in some synthetic mixtures.

\begin{tabular}{cccc}
\hline \multicolumn{2}{c}{$C_{\text {added }} / \mu \mathrm{mol} \mathrm{L}^{-1}$} & \multicolumn{2}{c}{$C_{\text {found }} / \mu \mathrm{mol} \mathrm{L}^{-1}$} \\
\hline TP & $\mathrm{GU}$ & $\mathrm{TP}$ & $\mathrm{GU}$ \\
40 & 40 & 40.2 & 40.2 \\
40 & 40 & 39.6 & 36.7 \\
40 & 40 & 38.4 & 39.1 \\
40 & 40 & 37.2 & 39.4 \\
40 & 40 & 38.2 & 46.7 \\
40 & 40 & 36.8 & 40.8 \\
Average & & 38.4 & 40.5 \\
Standard deviation & & 1.3 & 3.4 \\
10 & 10 & 10.4 & 10.0 \\
10 & 10 & 10.3 & 10.3 \\
10 & 10 & 9.6 & 10.7 \\
10 & 10 & 10.4 & 9.7 \\
10 & 10 & 10.2 & 10.8 \\
10 & 10 & 10.3 & 10.6 \\
Average & & 10.2 & 10.4 \\
Standard deviaton & & 0.3 & 0.4 \\
\hline
\end{tabular}




\section{Interferences}

For analyzing interferences, the influence of several ions and pharmaceutical compounds was tested, including those that most frequently accompany with guaifenesin and theophylline in pharmaceutical formulations. The effect of interfering species at different concentrations on the predicated concentration of a solution containing $10 \mu \mathrm{mol} \mathrm{L}^{-1}$ of both guaifenesin and theophylline was studied. A species was considered to interfere when its presence produced a variation in the $\mathrm{C}_{\mathrm{H}}$ of the sample greater than $10 \%$. As it has shown in Table 3, most ions do not interfere at high levels due to the fact that in alkali media, $\mathrm{pH}(>7.0)$, many cations precipitate in aqueous media.

Table 3. Maximum tolerable concentration of interfering species with guaifenesin $\left(10 \mu \mathrm{mol} \mathrm{L} \mathrm{L}^{-1}\right)$ and theophylline $\left(10 \mu \mathrm{mol} \mathrm{L}{ }^{-1}\right)$.

\begin{tabular}{lc}
\hline \multicolumn{1}{c}{ Species } & $\begin{array}{c}\text { Tolerance } \\
\text { concentration } / \mu \text { mol L }\end{array}$ \\
\hline $\mathrm{NO}_{3}^{-}, \mathrm{I}^{-}, \mathrm{K}^{+}, \mathrm{Mg}^{2+}, \mathrm{Ca}^{2+}, \mathrm{Na}^{+}, \mathrm{CH} 3 \mathrm{COO}^{-}$ & 10000 \\
$\mathrm{Cu}^{2+}, \mathrm{Co}^{2+}, \mathrm{Ag}^{+}, \mathrm{Br}^{-}, \mathrm{Cd}^{2+}, \mathrm{Fe}^{2+}, \mathrm{Zn}^{2+}$, & 1000 \\
$\mathrm{Ca}^{2+}, \mathrm{Al}^{3+}, \mathrm{Fe}^{3+}, \mathrm{PO}_{4}{ }_{4}^{3-}, \mathrm{SO}_{4}{ }^{2-}, \mathrm{Mn}^{2+}, \mathrm{CH}_{3} \mathrm{OH}, \mathrm{C}_{2} \mathrm{H}_{5} \mathrm{OH}$ & \\
${\mathrm{Vitamin} \mathrm{B}_{1}, \mathrm{Vitamin} \mathrm{B}_{6}, \mathrm{Vitamin}_{\mathrm{C}}, \mathrm{Folic} \text { acid, }}$ & 100 \\
Glucose, Sodium benzoate & \\
\hline
\end{tabular}

\section{Application}

For showing the applicability of the method, some biological fluids and cough syrup (theophylline G) with complex matrixes were spiked with guaifenesin and theophylline and proposed method was applied for simultaneous determination of the species. The results are shown in Table 4. The results showed that the proposed method can be applied for analysis of compounds in real samples with satisfactory results. Employing the proposed procedure on several synthetic samples showed that, $\mathrm{C}_{\mathrm{H}}$ (concentration of analyte) is independent of the concentration of interference. Limit of detection (LOD) was calculated as $\mathrm{LOD}=3 S_{\mathrm{CH}}$, were $S_{\mathrm{CH}}$ is the standard deviation of several $(n=6)$ replicated measurements of zero concentration of analyte with the HPSAM. The corresponding values obtained for guaifenesin and theophylline were 0.17 and $0.07 \mu \mathrm{mol} \mathrm{L}^{-1}$.

Table 4. Determination of guaifenesin and theophylline in some pharmaceutical formulations and biological fluids.

\begin{tabular}{ccccccc}
\hline \multirow{2}{*}{ Sample } & \multicolumn{2}{c}{$C_{\text {added }} / \mu \mathrm{mol} \mathrm{L}^{-1}$} & \multicolumn{2}{c}{$C_{\text {found }} / \mu \mathrm{mol} \mathrm{L}{ }^{-1}$} & \multicolumn{2}{c}{ Recovery } \\
\cline { 2 - 7 } & $\mathrm{GU}$ & $\mathrm{TP}$ & $\mathrm{GU}$ & $\mathrm{TP}$ & $\mathrm{GU}$ & $\mathrm{TP}$ \\
\hline Whole blood & --- & -- & $<\mathrm{DL}^{\mathrm{a}}$ & $<\mathrm{DL}$ & --- & -- \\
& 10.0 & 20.0 & $10.20 \pm 0.37^{\mathrm{b}}$ & $20.56 \pm 0.33$ & 102.0 & 102.8 \\
Plasma & 50.0 & 50.0 & $20.03 \pm 0.18$ & $10.55 \pm 0.27$ & 100.15 & 105.5 \\
& --- & -- & $<\mathrm{DL}$ & $<\mathrm{DL}$ & --- & -- \\
& 10.0 & 10.0 & $10.28 \pm 1.50$ & $9.86 \pm 0.58$ & 102.8 & 98.6 \\
Theophylline G & 50.0 & 50.0 & $47.99 \pm 2.47$ & $48.03 \pm 2.80$ & 96.0 & 96.1 \\
$\begin{array}{c}\text { Syrup } \\
\text { Theophylline } \\
\text { Syrup }\end{array}$ & --- & --- & $5.68 \pm 0.62$ & $9.66 \pm 0.72$ & 94.7 & 96.6 \\
\hline
\end{tabular}

${ }^{a}$ Detection Limit, ${ }^{b} \pm$ Confidence interval for 3 replicate determinations, ${ }^{*}$ Each $1 \mathrm{~mL}$ of syrup contains $10 \mathrm{mg}$ theophylline and $6 \mathrm{mg}$ guaifenesin from Daroo Pakhsh Co., ${ }^{* *}$ Each $1 \mathrm{~mL}$ of syrup contains 10 $\mathrm{mg}$ theophylline and $6 \mathrm{mg}$ guaifenesin from Razak Co. 


\section{Conclusion}

This study demonstrates the ability of the HPSAM to provide a concentration of an analyte, guaifenesin or theophylline, in the presence of each other, and to estimate the appropriate compounds simultaneously by the combination of HPSAM-first derivative spectrophotometry. The principal advantage of this method is in contrast to derivative spectrophotometry, we are not limited to zero-crossing wavelenths. The wavelengths are selected base on HPSAM on first derivative spectra. Analysis of the prepared binary mixtures of guaifenesin and theophylline showed that their simultaneous determination is possible in a wide range of mole ratios. The proposed method offers satisfactory selectivity, sensitivity, accuracy and reproducibility.

\section{Acknowledgment}

The authors gratefully acknowledge the support of this work by Islamic Azad University Branch of Gachsaran (IAUG). Also the assistance of Ramopharmin and Doctor Abidi Medical pharmaceutical companies for offering pure drugs is gratefully acknowledged.

\section{References}

1. Expectorant Drug Products for Over-the-Counter Human Use; Final Monograph. U.S. Department of Health and Human Services. Federal Register, 1989, 54, 8494-8509.

2. Dicpinigaitis P V and Gayle Y E, Chest., 2003, 124(6), 2178-2181.

3. Robinson R E, Cummings W B and Deffenbaugh E R, Curr Ther Res., 1977, 22, 284-296.

4. Abuirjeie M A, El-din M S and Mahmoud I I, J Liq Chromatogr., 1992, 15, 101-125.

5. Stavriv B, Food Chem Toxicol., 1998, 26, 645.

6. Dockendorff B, Holman D A, Christian G D and Ruzicka J, Anal Commun., 1998, 35, 357-359.

7. Howard C E, Capers C C, Bess D T and Anderson R J, Am. J Hosp Pharm., 1994, $\mathbf{5 1}, 1672$.

8. Slamenova D, Chalupa I, Gabelova A, Bozsakyova E, Horvathov E and Blasko M, Altern Lab Anim., 1995, 23, 504-512.

9. Hardman J G, Limbird L E and Gilman A G, Goodman \& Gilman's The Pharmacological Basis of Therapeutics, 10 ${ }^{\text {th }}$. Ed., McGraw-Hill Professional, NY, 2001.

10. USP28-NF23, the United States Pharmacopoeial Convention, Inc., Twin brooks Parkway, 2005.

11. Pokrajac M and Varagic V M, Acta Pharm Jugosl., 1983, 33, 23-27.

12. Davis J D, Aarons L and Houston J B, J Chromatogr., 1993, 621(1), 105109.

13. Iwase H, Gondo K, Koike T and Ono I, J Chromatogr B Biomed Appl., 1994, 655(1), 73-81.

14. Moncrieff J, J Chromatogr., 1991, 568, 177

15. Deravajan P V, Sule P N and Parmar D V, J Chromatogr B Biomed Sci Appl., 1999, 736, 289-293.

16. Lee B I, Jacob P and Benowitz N L, J Chromatogr., 1989, 494, 109.

17. Desage M, Soubeyrand J, Soun A, Brazier J L and Georges Y, J Chromatogr., 1984, 336, 285-291.

18. Torrecilla-Junyent M T, Navarro-Ruiz P A, Izquierdo-Maria R and Navarro-Polo J N, Farm Clin Spain., 1992, 9, 168-170.

19. Climent E, Valiente F, Selva J and Alamo J M, Farm Clin Spain., 1994, 11, 428-430.

20. Canto-Pascual M M, Alos-Alminana M, Magraner-Gil J, Ezquer-Borras J and Torrecilla-Junyent M T, Farm Clin Spain, 1987, 4, 40-42.

21. Roscoeand R and Vitti T, Can J Pharm Sci., 1980, 15(3), 69-70. 
22. Zhang Z Y, Fasco M J and Kaminsky L S, J Chromatogr B Biomed Appl., 1995, 665(1), 201-208.

23. Johansson I M, Gron-Rydberg M B and Schmekel B, J Chromatogr A., 1993, 652, 487-493.

24. Kuzuya T, Ogura Y, Hasegawa M, Nakamura T A and Kitazawa S, J Hosp Pharm Assoc Sci., 1986, 12, 362-368.

25. Kuzuya T, Ogura Y, Hasegawa M, Nakamura T A and Kitazawa S, J Nippon Hosp Pharm Assoc Sci Ed., 1986, 12, 362-368.

26. Galli V and Barbas C, J Chromatogr A, 2004, 1048, 207-211.

27. Wilson T D, Jump W G, Neumann W C and San Martin T, J Chromatogr., 1993, 641, 241.

28. Gupta V D and Ghanekar A G, J Pharm Sci., 1977, 66, 895-897.

29. Muhammad N and Bodnar J A, J Liq Chromatogr., 1980, 3, 113-122.

30. Vogt C, Conradi S and Rohde E, J Chem Educ., 1997, 74, 1126-1130.

31. Vadeginste B G M, Massart D L, Buydens L M C, De Jong S, Lewi P J and SmeyersVerbeke J, Handbook of Chemometrics and Qualimetrics, Elsevier, Amsterdam 1998.

32. Saxberg B E H and Kowalski B R, Anal Chem., 1979, 51, 1031-1038.

33. Bosch-Reig F and Campins-Falco P, Analyst, 1988, 113, 1011.

34. Bosch-Reig F and Campins-Falco P, Analyst, 1990, 115, 111.

35. Campins-Falco P, Bosch-Reig F and Benet A M, Fresenius J Anal Chem., 1990, 338, 16.

36. Campins-Falco P, Bosch-Reig F and Verdu-Andres J, J Anal Chim Acta., 1992, 270, 253.

37. Campins-Falco P, Bosch-Reig F, Verdu-Andres J and Molins Legua C, Talanta, 1994, 41, 39.

38. Abdollahi H, Anal Chim Acta., 2001, 442, 327.

39. Campins-Falco P, Verdu-Andres J and Bosch-Reig F, Analyst, 1994, 119, 2123.

40. Safavi A, Abdollahi H, Sedaghatpour F and Zeinali S, Anal Chim Acta., 2000, 409, 275.

41. Safavi A, Abdollahi H and Hormozi Nezhad M R, Talanta, 2002, 56(4), 699-704.

42. Campins-Falco P, Bosch-Reig F, Herraez-Hernandez R, Cabeza A S and Legua C M, Anal Chem., 1991, 63, 2424.

43. Gomez F B, Campins-Falco P, Bosch-Reig F, Molins Legua C and HerraezHernandez R, Anal Chem., 2000, 72, 2559.

44. Shams E, Abdollahi H, Yekehtaz M and Hajian R, Talanta, 2004, 63, 359.

45. Shams E, Abdollahi H and Hajian R, Electroanalysis, 2005, 17, 1589.

46. Ensafi A A and Hajian R, Anal Chim Acta, 2006, 580, 236-243.

47. Safavi A, Abdollahi H and Bagheri M, Anal Chim Acta, 2002, 459, 119.

48. Abdollahi H and Zeinali S, Talanta, 2004, 62, 151-163.

49. Campins-Falco P, Verdu-Andres J and Bosch-Reig F, Anal Chim Acta, 1995, 315, 267.

50. Reig F B, Falco P C, Hernandez B H and Cabeza A S, Anal Chim Acta, 1992, 257, 89.

51. Safavi A and Abdollahi H, Talanta, 2001, 54, 727-734. 


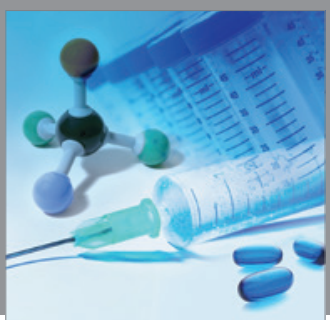

International Journal of

Medicinal Chemistry

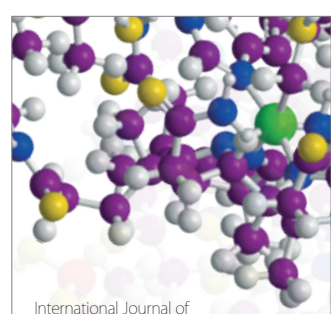

Carbohydrate Chemistry

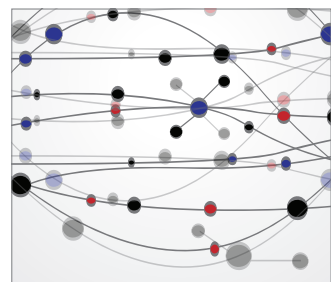

The Scientific World Journal
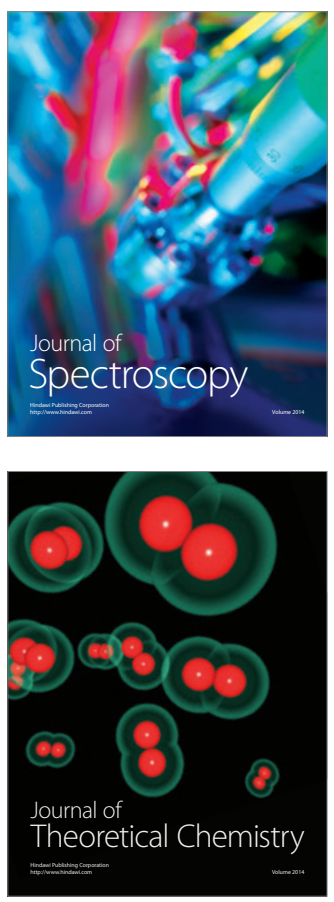
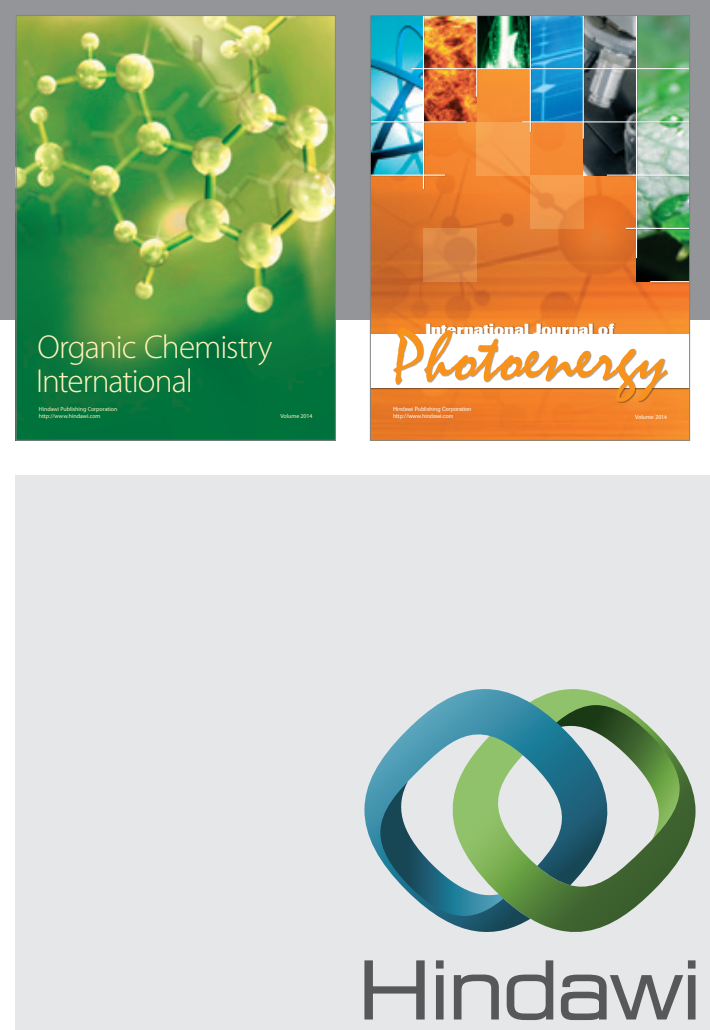

Submit your manuscripts at

http://www.hindawi.com
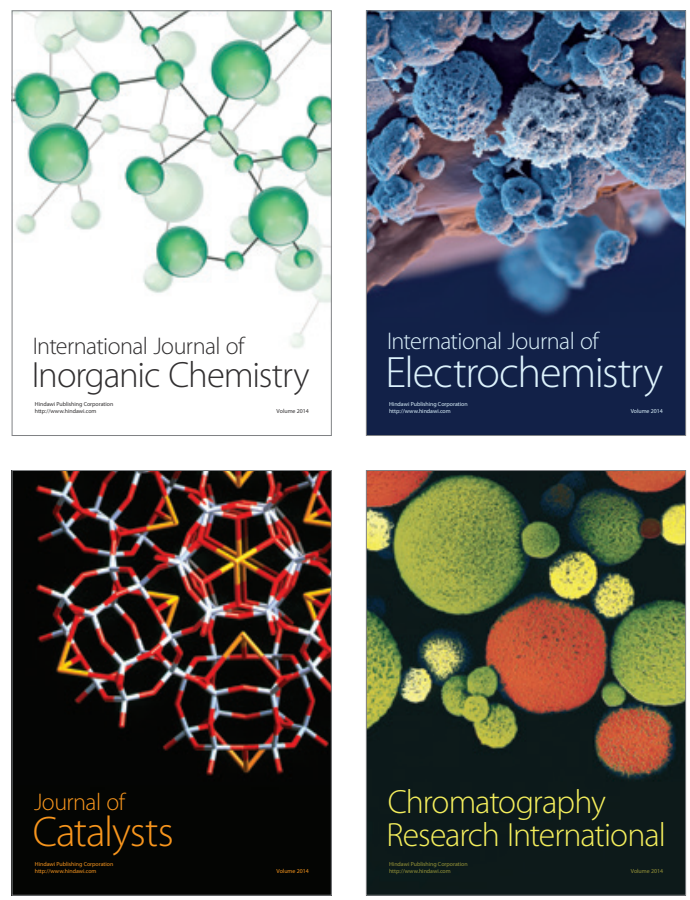
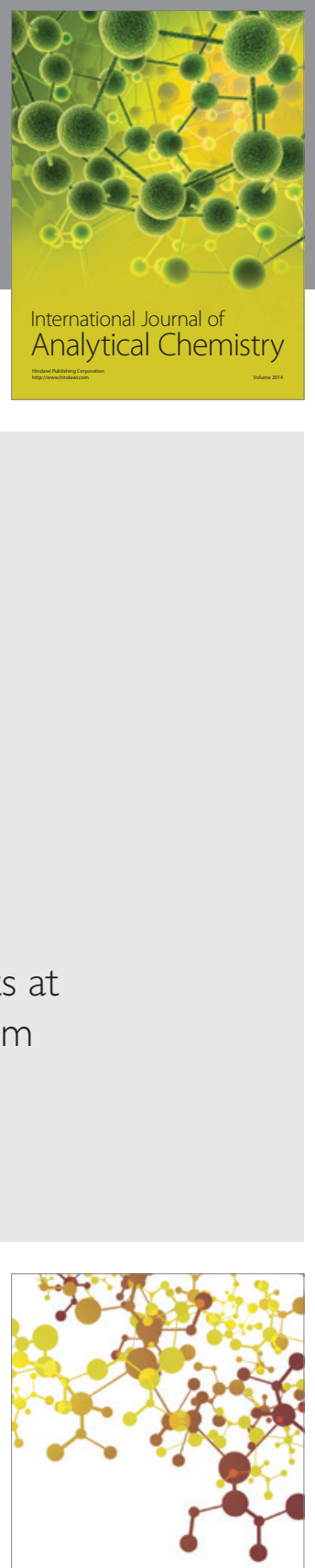

Journal of

Applied Chemistry
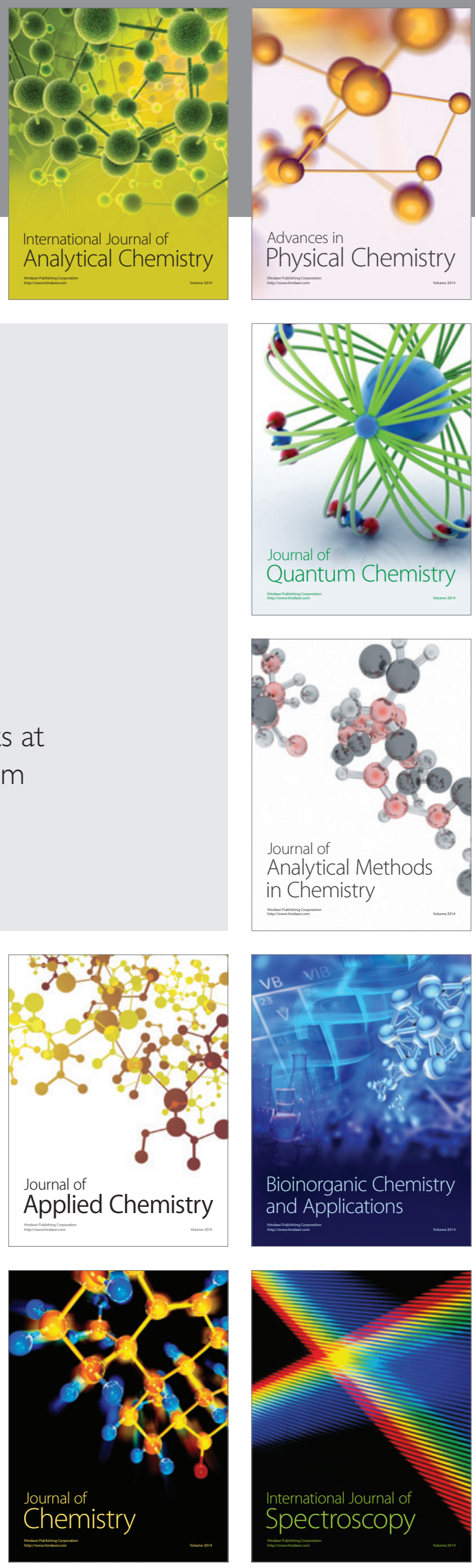